The Open Dentistry Journal
Bentham OPEN
CrossMark
DOI: $10.2174 / 1874210601812010424$

REVIEW ARTICLE

\title{
Oral Aspects Identified in Atopic Dermatitis Patients: A Literature Review
}

Aline Domingues Tavares Oliveira ${ }^{5}$, Camila Stofella Sodré ${ }^{4}$, Dennis de Carvalho Ferreira ${ }^{3,5}$, Eliane de Dios Abad ${ }^{6}$, Simone Saintive ${ }^{5}$, Márcia Ribeiro ${ }^{7}$, Fernanda Sampaio Cavalcante ${ }^{1}$, Bruna Piciani ${ }^{2}$ and Lucio Souza Gonçalves ${ }^{3, *}$

${ }^{I}$ Department of Microbiology, Federal University of Rio de Janeiro, Rio de Janeiro, Brazil

${ }^{2}$ Department of Pathology, Fluminense Federal University, Rio de Janeiro, Brazil

${ }^{3}$ Faculty of Dentistry, Estácio de Sá University, Rio de Janeiro, Brazil

${ }^{4}$ Department of Clinical Medicine, Federal University of Rio de Janeiro, Rio de Janeiro, Brazil

${ }^{5}$ Faculty of Dentistry, Veiga de Almeida University, Rio de Janeiro, Brazil

${ }^{6}$ Pediatric Dermatology Service, Federal University of Rio de Janeiro, Rio de Janeiro, Brazil

${ }^{7}$ Medical Genetics Service, Federal University of Rio de Janeiro, Rio de Janeiro, Brazil

Received: March 20, 2018

Revised: April 26, 2018

Accepted: May 14, 2018

\section{Abstract:}

\section{Introduction:}

Atopic dermatitis is a chronic inflammatory skin condition that is more prevalent in children (10-20\% of the world's population) than in adults. As its etiology is multifactorial, it is important to know the most frequent oral manifestations in atopic dermatitis patients.

\section{Methodology:}

In the last decades, the correlation between atopic dermatitis and conditions and/or changes in the oral cavity has been demonstrated by several studies. The objective of this paper was to describe, through a review of the literature, the oral health conditions and/or oral aspects identified in patients with atopic dermatitis.

\section{Search Strategy:}

A descriptive literature review was carried out through a bibliographical survey based on the last 10 years, in order to answer the study questions.

\section{Results:}

As a result, we found six studies with different sample sizes, ranging from 43 to 468 patients, and the majority of them were of crosssectional study design.

\section{Discussion:}

Two studies performed their analysis through dental exams and reported that patients with atopic dermatitis tend to have a greater frequency of carious lesions, and two studies correlated Candida with atopic dermatitis through mycological analyzes.

\footnotetext{
* Address correspondence to the author at the Faculty of Dentistry, Estácio de Sá University, Av. Alfredo Baltazar da Silveira, 580/cobertura, CEP: 22790-010 - Recreio - Rio de Janeiro/RJ - Brazil; Tel: 5521 994550040; E-mail: luciogoncalves@yahoo.com.br
} 


\section{Conclusion:}

There are a few studies in the literature that identify the oral aspects of atopic dermatitis. More investigations are needed in order to contribute to the knowledge of such oral aspects and the approach to treat these patients regarding oral health.

Keywords: Atopic dermatitis, Oral manifestations, Dental caries, Xeroderma, Nasopharyngeal mucosa, Chronic inflammatory skin condition.

\section{INTRODUCTION}

Atopic Dermatitis (AD) is a chronic inflammatory skin condition that can be accompanied by asthma and other manifestations of atopy. Among the clinical features of AD are intense pruritus, xeroderma, and recurrent eczema, which may be acute, subacute or chronic [1 - 3]. There are periods of improvement and exacerbation, and such symptoms are often present in other family members [4 - 6].

$\mathrm{AD}$ diagnosis is clinical and is based on the criteria suggested by Hanifin and Hajka [7], as there is no specific laboratory marker. Control of the disease and treatment of exacerbations is carried out by environmental control, avoiding triggering factors, such as dust and cooling air. Also, skin care and topical or systemic drug treatment depending on the severity of the condition can be used as preventing strategies. One of the main drugs used in dermatology are topical corticosteroids. However, due to the chronic and recurrent character of AD, immunosuppressive drugs, such as cyclosporine A, methotrexate, azathioprine, or mycophenolic acid are sometimes necessary [8].

Over the last few years, various studies have tried to identify factors that exacerbate AD. One example is the research related to $\mathrm{AD}$ and intestinal microbioma [9]. Another factor that has not been adequately addressed is the oral health of children with AD. This is still an issue, despite its importance.

Studies, since 1987, have demonstrated the correlation between atopic dermatitis and manifestations and/or changes in the oral cavity. For example, the study by Hannuksela and Väänänen [10] conducted a survey to determine the types and prevalence of malocclusions in a group of 217 7-year-old children, of which 82 children had symptoms of atopy. These authors observed that atopic dermatitis was correlated to posterior crossbite and atypical swallowing. Congruently, it is known that atopic diseases generally increase the frequency of class I occlusion and reduced overbite, and that the development of crossbite and other changes in the dentition may be associated with the fact that the nasopharyngeal mucosa is hyperreactive in children with $\mathrm{AD}[10]$.

In 2000, in a study with 24 patients with atopic dermatitis and 7 with other dermatological diseases, Yoshida and Amatsu investigated whether the dermatological manifestations in the face of patients with AD could reactivate the latent Herpes Simplex Virus Type 1 (HSV-1) in the trigeminal ganglion, causing an asymptomatic excretion of this virus in the oral cavity. Although the results were not conclusive, according to the authors, there is a possibility that HVS-1 in the oral cavity can infect the skin in other locations, since recurrent skin lesions may be a trigger for herpetic eczema in patients presenting recurrent episodes of eczema [11].

Some authors have reported that atopic patients with high serum IgE levels are more likely to present a Geographic Tongue (GT) [12 - 14]. One possible explanation for this is that psychosomatic factors and acute inflammatory conditions contribute to the emergence of both conditions. Although GT is not a specific feature of atopy, it is a condition that may be associated with atopic disorders and is often observed before the onset of atopy symptoms. The only study found in the literature that evaluated oral changes in patients with atopic dermatitis concluded that $\mathrm{AD}$ is not associated with GT [12 - 14]. The etiology of GT remains obscure, but it is known to have a chronic, inflammatory and immunomediated profile, with the involvement of cytokines. In view of these similarities with AD, further studies are needed to confirm whether there is a type of GT that is associated with AD [12 - 14].

Among some of the minor criteria for the diagnosis of atopic dermatitis established by Hanifin and Hajka [3] is atopic cheilitis, a condition that causes "redness" due to mechanical stress and environmental and physiological factors. Such manifestation creates difficulty to treat the site where there is a persistent defect of the epithelial barrier [15].

The prevalence of $\mathrm{AD}$ around the world has increased over the last 30 years and is now found in Africa, East Asia, Western Europe, parts of Northern Europe and has affected as much as $18 \%$ of the population in the United States [16, 17]. This increase may be due to changes in the pattern of environmental pollutants, a reduction in breastfeeding, an increase in sensitivity of the individuals involved, improved personal hygiene, a reduced risk of infections during childhood and consequently an increase in sensitivity to allergens, and in urbanization, with a higher prevalence of $\mathrm{AD}$ 
in urban settings [7]. The incidence of AD is higher in children (10-20\%), than in adults where it is only $1-3 \%$ [8].

The diagnosis of AD is complex as there is still yet no effective specific laboratory marker, and only a pre-clinical diagnosis has been made, which is defined according to the primary and secondary criteria recommended by Hanifin and Hajka [3] and/or by Williams et al. [18]. The treatment is based on the exclusion of the environmental causes such as dust and weather conditions; and association with topical corticosteroids. However, due to factors such as frequent recurrence, rebound of the disease, due to the use of potent topical corticosteroids, the literature suggests new therapeutic alternatives for patients with $\mathrm{AD}$ [19]. Despite all the recent information found in the literature, the oral health of children with AD is still insufficiently addressed especially since certain important factors, concerning oral health, influence the daily life of patients with AD.

Chronic diseases such as atopic dermatitis usually have a multifactorial etiology, and therefore their diagnosis and clinical follow-up require a multidisciplinary professional approach in which dentistry plays a prominent role as the oral cavity frequently signals or evidences important manifestations of such diseases [20].

Since 1987, studies have demonstrated correlations between atopic dermatitis and possible manifestations/ alterations in the oral cavity such as an increased frequency of class I occlusion, reduced overbite, susceptibility to cariogenic activity, reactivation of the Herpes Simplex Virus type 1 (HSV-1), causing its release into the oral cavity, and the worsening of $\mathrm{AD}$ in patients with odontogenic focal infections. Moreover, the use of inhaled corticosteroids contributes to the development of candidiasis [10, 11,21 - 25].

Although there are few studies linking atopic dermatitis to oral aspects, this aspect of AD is clearly still a topic that should be investigated further. Therefore, the objective of this work was to describe, through a review of the literature, the oral health conditions and/or aspects identified in patients with atopic dermatitis using articles published over the last 10 years.

\section{METHODOLOGY AND SEARCH STRATEGY}

This research was carried out via a literature review [26]. This study came from a research project in atopic dermatitis that had an interdisciplinary microbiological and care practices approach that included oral health. The project aimed to promote care and quality of life for AD patients. The oral aspects were highlighted so that the (dental) professionals were more prepared to assist these patients and could formulate strategies of intervention. The following (guideline) questions were prepared to carry out the present review: What oral aspects were identified in the scientific literature as being related to patients with atopic dermatitis? Did these findings correlate with the severity of AD?

The bibliographical survey consisted primarily of five online databases: PubMed, the Scientific Electronic Library Online (SciELO), Scholar Google, Latin American and Caribbean Health Sciences (LilaCS), and the Brazilian Dentistry Library (BBO). As the search criteria, documents published and found in the "advanced search" mode were investigated, using cross-correlation with the following keywords: "atopic dermatitis", "oral manifestations", "mouth", "oral pathology", "dental caries" and "stomatognathic diseases" which were identified and selected according to the addressed subject. Also, the AND operator was used in these searches. These words were selected because they related to the topic of interest and were previously checked in the MeSH of Medline. Also, the terms "childhood" and "dental disorders" were included although they were not directly described in the MeSH.

The articles were selected from each database following the inclusion criteria: Title and Abstract of the article compatible and related to the topic of interest; published in full in the following languages: Portuguese and/or English; published and/or available online from January 2006 to January 2016; and based on original research and/or clinical case reports. Theses, books, dissertations, patents, literature reviews and articles whose theme was not related to the purpose of the study were excluded.

\section{RESULTS}

The initial search for articles resulted in a total of 24,368 from PubMed articles, 169 articles from ScieLo, 33,188 from Google Academic, 405 from LilaCS and no articles from BBO (Fig. 1). After applying the inclusion and exclusion criteria, 6 studies were selected for the review (Table 1). 


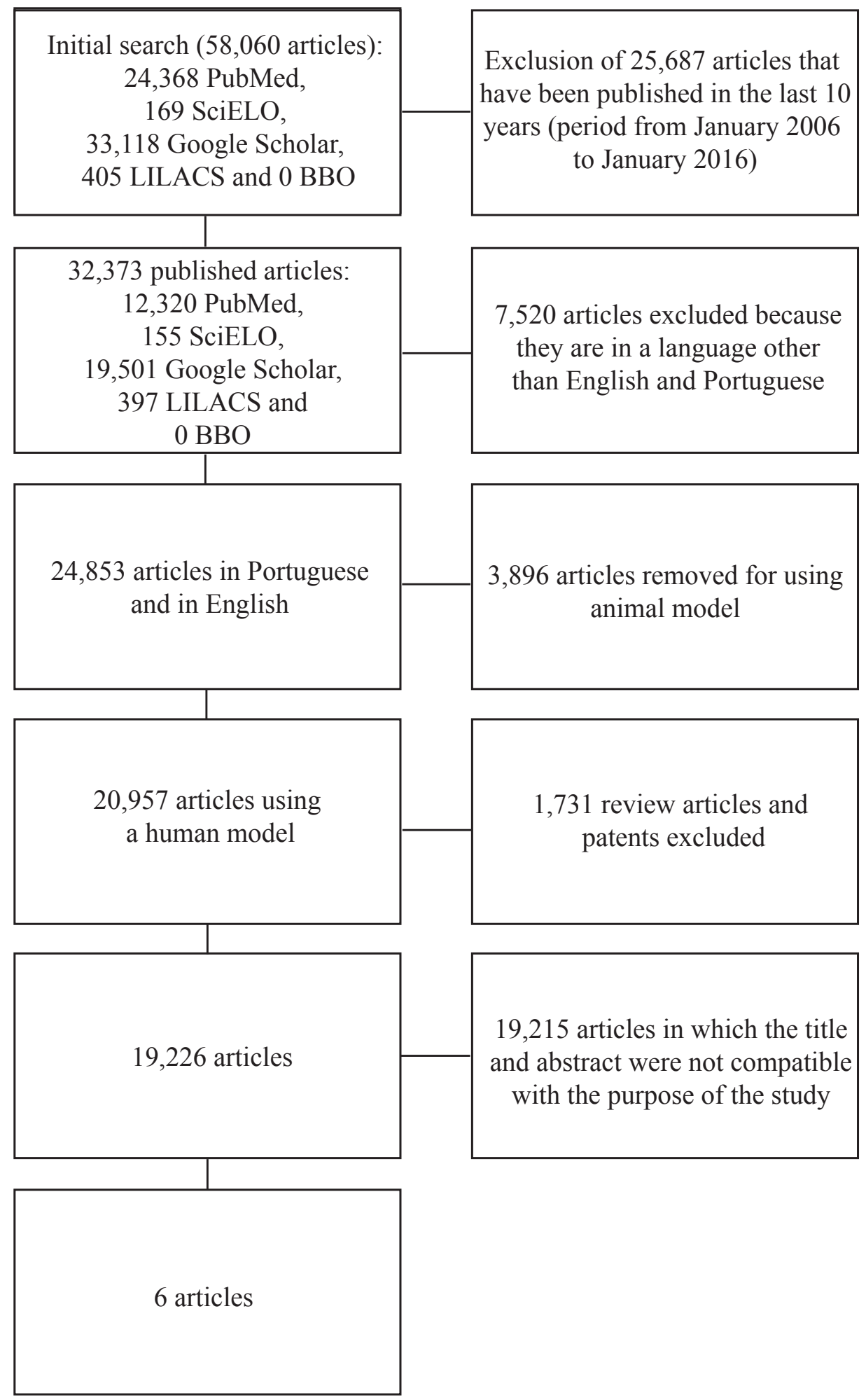

Fig. (1). Article selection methodology. 
Table 1. Characteristics of some of the studies included in this paper.

\begin{tabular}{|c|c|c|c|c|c|c|}
\hline $\begin{array}{c}\text { Author, } \\
\text { Country and } \\
\text { Year }\end{array}$ & Goals & Databases & Keywords & Sample Size & $\begin{array}{l}\text { Type of } \\
\text { Study }\end{array}$ & $\begin{array}{c}\text { Factors Associated with Atopic } \\
\text { Dermatitis }\end{array}$ \\
\hline $\begin{array}{l}\text { Yamaguchi } \mathrm{H} \\
\text { et al. } \\
\text { Japan, } 2015\end{array}$ & $\begin{array}{c}\text { To evaluate if mouth breathing } \\
\text { is associated with other types of } \\
\text { diseases including atopic } \\
\text { dermatitis through a } \\
\text { questionnaire aimed at pre- } \\
\text { school children in day care } \\
\text { centers }\end{array}$ & $\begin{array}{l}\text { PubMed; } \\
\text { Google } \\
\text { Scholar }\end{array}$ & $\begin{array}{l}\text { Atopic } \\
\text { dermatitis; } \\
\text { mouth }\end{array}$ & $\begin{array}{l}468 \text { children } \\
\text { Age: } 2-6 \text { years old } \\
-59 \text { children with } \\
\text { atopic dermatitis; } \\
\text {-46 children with } \\
\text { asthma; } \\
\text {-61 children with } \\
\text { allergic rhinitis }\end{array}$ & Sectional & $\begin{array}{l}\text { Daytime and nighttime (during } \\
\text { sleep) mouth breathing in children } \\
\text { with AD was associated with: } \\
\text { history of allergic rhinitis, history } \\
\text { of asthma, and family history of } \\
\text { atopic dermatitis }\end{array}$ \\
\hline $\begin{array}{l}\text { Javad G et al. } \\
\text { Iran, } 2015\end{array}$ & $\begin{array}{l}\text { To verify the colonization of } \\
\text { Candida and the specific } \\
\text { humoral response against } \\
\text { Candida albicans in patients } \\
\text { with atopic dermatitis }\end{array}$ & PubMed & $\begin{array}{l}\text { Atopic } \\
\text { dermatitis; } \\
\text { mouth; oral } \\
\text { pathology }\end{array}$ & $\begin{array}{l}\text { - } 100 \text { patients with } \\
\text { AD } \\
\text { - mean age of } 12.1 \pm \\
11.5 \text { years old; } \\
\text { - } 50 \text { healthy subjects } \\
\text { (control group) with a } \\
\text { mean age of } 39.9 \pm \\
11.45 \text { years old }\end{array}$ & Sectional & $\begin{array}{l}\text { There was no statistically } \\
\text { significant difference in relation } \\
\text { to: Candida colonization in } \\
\text { patients with atopic dermatitis and } \\
\text { those in the control group; and } \\
\text { between the IgM and IgA serum } \\
\text { levels of the patients and controls. } \\
\text { Candida was isolated from the } \\
\text { oral cavity of } 23 \% \text { of the patients } \\
\text { with AD and } 6 \% \text { of the individuals } \\
\text { in the healthy group. }\end{array}$ \\
\hline $\begin{array}{l}\text { Leibovici V } \\
\text { et al. } \\
\text { Israel, } 2007\end{array}$ & $\begin{array}{l}\text { To determine the presence of } \\
\text { Candida in the following } \\
\text { locations: armpit, tongue and } \\
\text { groin of patients with psoriasis } \\
\text { and compared to patients with } \\
\text { atopic dermatitis and normal } \\
\text { controls. }\end{array}$ & PubMed & $\begin{array}{l}\text { Atopic } \\
\text { dermatitis; } \\
\text { mouth; dental } \\
\text { disorders }\end{array}$ & $\begin{array}{l}\text { - } 100 \text { adult patients } \\
\text { with psoriasis aged } \\
\text { from } 18 \text { to } 84 \text { years } \\
\text { old; } \\
\text { - } 100 \text { adult patients } \\
\text { with AD aged from } 18 \\
\text { to } 83 \text { years old; } \\
\text { - } 100 \text { normal controls } \\
\text { aged from } 18 \text { to } 80 \\
\text { years old }\end{array}$ & Sectional & $\begin{array}{l}\text { Low prevalence of Candida on the } \\
\text { tongue of patients with atopic } \\
\text { dermatitis }(18 \%) \text { compared to } \\
\text { patients with psoriasis }(32 \%) \text { and } \\
\text { normal controls }(21 \%) \text {. }\end{array}$ \\
\hline $\begin{array}{l}\text { Igawa K, } \\
\text { Nishioka K, } \\
\text { Yokozeki H } \\
\text { Japan, } 2007\end{array}$ & $\begin{array}{c}\text { To verify if a odontogenic focal } \\
\text { infection is an aggravating } \\
\text { factor in atopic dermatitis }\end{array}$ & PubMed & $\begin{array}{l}\text { Atopic } \\
\text { dermatitis, } \\
\text { mouth; dental } \\
\text { disorders }\end{array}$ & $\begin{array}{l}\text { - } 43 \text { adolescent and } \\
\text { adult patients aged } \\
\text { from } 13 \text { to } 62 \text { years } \\
\text { old and with chronic } \\
\text { AD }\end{array}$ & Cohort & $\begin{array}{l}\text { Patients with } \mathrm{AD} \text { and an } \\
\text { odontogenic focal infection had a } \\
\text { greater improvement after } 3 \\
\text { months of dental treatment } \\
\text { compared to patients who did not } \\
\text { have odontogenic focal infection } \\
\text { but who received dental treatment. }\end{array}$ \\
\hline $\begin{array}{l}\text { Mizawa M } \\
\text { et al. } \\
\text { Japan, } 2013\end{array}$ & $\begin{array}{l}\text { To evaluate salivary cortisol } \\
\text { levels in patients with atopic } \\
\text { dermatitis and to compare them } \\
\text { with a healthy control group }\end{array}$ & PubMed & $\begin{array}{c}\text { Atopic } \\
\text { dermatitis }\end{array}$ & $\begin{array}{l}\text { - } 30 \text { patients with } \mathrm{AD} \\
\text { aged from } 15 \text { to } 62 \\
\text { years old; } \\
\text { - } 42 \text { systematically } \\
\text { healthy individuals } \\
\text { aged from } 31 \text { to } 54 \\
\text { years old } \\
\text { (group control) }\end{array}$ & Sectional & $\begin{array}{l}\text { The salivary cortisol levels of } \\
\text { patients with atopic dermatitis } \\
\text { were significantly higher than } \\
\text { those of the control group }\end{array}$ \\
\hline $\begin{array}{l}\text { Perugia C } \\
\quad \text { et al. } \\
\text { Italy, } 2015\end{array}$ & $\begin{array}{l}\text { Verify the possible correlation } \\
\text { between atopic dermatitis and } \\
\text { oral manifestations in pediatric } \\
\text { patients; }\end{array}$ & PubMed & $\begin{array}{l}\text { Atopic } \\
\text { dermatitis; } \\
\text { caries }\end{array}$ & $\begin{array}{c}300 \text { children } \\
\text { (from } 2 \text { to } 17 \text { years } \\
\text { old) } \\
\text { - } 90 \text { children }(30 \%) \\
\text { with AD; } \\
\text {-210 children without } \\
\text { AD }\end{array}$ & Sectional & $\begin{array}{c}\text { Children with AD } \\
\text { presented: } \\
\text { - medical history of spoil habit } \\
(76 \%) \text {; } \\
\text { - presence of dental caries }(56 \%) \text {; } \\
\text { - dental malocclusion }(64.4 \%) \text {. }\end{array}$ \\
\hline
\end{tabular}

The sample size in the studies selected was very diverse, ranging from 43 to 468 patients. Most articles were observational, cross-sectional (5/6 studies) and all used the English language (6/6 articles). In relation to the severity criteria of AD, 2 studies [22, 27] used SCORAD as the criterion for severity of AD, while 2 other studies [21, 28] used EASI (Eczema Area and Severity Index) [3]. The other 2 studies [29, 30] did not assess the severity of AD. Yamaguchi et al. [29] used the mouth breathing criterion from a questionnaire carried out with pre-school children. In this case, atopic dermatitis was evaluated in conjunction with other conditions, such as asthma and allergic rhinitis, among others which were found using the questionnaire. 
The microbiological analyzes of two studies [22, 27] detected the presence of Candida albicans with atopic dermatitis through mycological analyzes. The latter also used PCR for the D1/D2 domain of the ribosomal subunit gene (26S) and sequencing. Serum $\operatorname{IgG}$, IgM and $\operatorname{IgA}$ antibodies were also detected by ELISA using anti-C. albicans antibodies.

The other studies followed different methodologies, such as evaluating the presence of root caries in 43 patients with chronic atopic dermatitis resistant to conventional therapy and who were reassessed 3 months after receiving dental treatment. In this study, the AD patients with an odontogenic focal infection showed a greater improvement in the EASI score after dental treatment in relation to the group that did not receive the dental treatment [21]. Another study evaluated salivary cortisol levels [28] demonstrating that the level of salivary cortisol in patients with AD was higher than in the control group.

Yamaguchi et al. [29] used a questionnaire to evaluate the relationship between mouth breathing and atopic dermatitis, in which the subjects were divided into three groups: patients with AD, asthma and allergic rhinitis. The results showed there were associations between $\mathrm{AD}$ and mouth breathing during the day and during sleep. Another study with 300 patients, $90(30 \%)$ with $\mathrm{AD}$, assessed the oral health conditions, through the presence of carious lesions and examination of the soft tissues. Here the results showed a high prevalence of medical history of spoil habit in $76.6 \%$ of the children and adolescents studied: thumb sucking (36 children), tongue protrusion (11 children), infantile swallowing (40 children), mouth breathing (17 children), onychophagia (15 children), alterations in the dental anatomy (13 children), agenesis ( 5 children), hypoplasias ( 7 children), dental caries (49 children) and dental malocclusions (58 children) [30].

\section{DISCUSSION}

Our group focuses on improving the quality of life for children with dermatological diseases, as well as scientific research in atopic dermatitis, in particular, which is one of the most frequent and disturbing diseases in childhood [20, 31]. The oral health of patients with $\mathrm{AD}$ is still an underexplored subject, although some studies have shown a correlation of $\mathrm{AD}$ with the presence of oral manifestations.

Igawa et al. [21] coined the term odontogenic focal infection to describe root caries in their study. These authors reported that this type of infection could contribute, based on previous studies that found a relationship between focal infections and psoriasis, to the worsening of atopic dermatitis. The authors evaluated 43 patients with chronic $\mathrm{AD}$, who were resistant to conventional therapy. Although root caries (active/silent) were asymptomatic and were present in some patients, all the patients underwent radiographic examination and were treated with conventional therapy, and when necessary, dental treatment, including dental extractions, was carried out [20]. The results showed that the patients had a significant improvement in the severity of AD after 3 months of treatment. This improvement was especially noticeable in the group of patients who had root caries, and who obtained a significantly greater improvement than the control group. The total number of patients, in this study, who had carious lesions was much lower than the number of patients in the study by Perugia et al. [30] with 300 children and adolescents of both genders, of whom almost 90 had AD. The patients with $\mathrm{AD}$ had a high prevalence of carious lesions (54\%) and dental malocclusion (64,4\%), suggesting the role of an odontogenic focal infection or presence of carious lesions as possible AD aggravating factors [20, 30]. These same authors also described medical history of spoil habit (76.6\%) such as thumb sucking, infantile swallowing and mouth breathing and dental alterations in $14.4 \%$ of the children, such as agenesis and hypoplasias.

Outpatients with moderate or severe AD are nearly always treated with corticosteroids, immunosuppressants/ immunomodulators, and antibiotics. However, these drugs, especially inhaled corticosteroids, favor the occurrence of Candidiasis, increasing the cariogenic activity due to the symbiosis relationship between Streptococcus mutans and Candida albicans [24].

Some liquid oral antibiotics also have cariogenic potential, as they contain components such as sugars and acids, which are added for the purpose of improving their taste, bioavailability and chemical stability [32]. The ability of an antibiotic to affect tooth enamel can be calculated mathematically by the Data Envelopment Analysis (DEA) methodology. This technique considers undesirable (high sugar concentration, low $\mathrm{pH}$, high $\mathrm{pH}$-titration and high viscosity) and desirable characteristics (absence of sugars, high $\mathrm{pH}$, low $\mathrm{pH}$-titration and low viscosity) to evaluate the performance of the antibiotic. The performance can vary from 0 to $100 \%$ and the lower the value, the greater the probability of attack on dental enamel.

Currently, the most commonly prescribed antibiotic for pediatric patients with $\mathrm{AD}$ and with an infection is 
cephalexin [33]. First-generation cephalosporins, including cephalexin, are recommended in the main guidelines for the treatment of staphylococcal infections as first-line therapy. Moreover, this is because they are antimicrobials of good tolerability, low cost, are taken orally and they are active against both Gram-positive and Gram-negative bacteria [34]. The DEA methodology indicates that the performance of Cephalexin, in dosages of $500 \mathrm{Mg}$, is $62 \%$. This value is associated with a greater possibility of dental enamel dissolution, allowing erosion and a risk of cariogenic activity. However, at a lower dosage of $250 \mathrm{mg}$, the antibiotic has a DEA percentage value of $100 \%$, indicating a low probability of affecting tooth enamel [32].

In addition to the intrinsic characteristics of antibiotics, the relationship between xerostomia and salivary flow is another factor to be discussed in the cariogenicity of these drugs, due to the important function of the salivary flow in the prevention of caries. Drugs that cause a decrease in salivary flow include the antihistamines, which are often used by patients with atopic dermatitis. They have side effects on the Central Nervous System (CNS) and antimuscarinic effects including dry mouth. These effects occur due to the inhibition of the M3 receptors present in the salivary glands. Decreased salivary flow is conducive to cariogenic activity. Immunosuppressants, especially systemic and inhaled corticosteroids, are also commonly related to opportunistic oral infections. This is due to their suppressive action of inflammatory activity, which also prevents the action of T lymphocytes, macrophages and some enzymes, among others [35]. Thus, as already stated, Candida albicans is characterized as a commensal microorganism of the oral cavity of adults and children without presenting oral manifestations [36, 37]. However, in the presence of predisposing factors that may be present in $\mathrm{AD}$, such as the use of broad-spectrum antibiotics, xerostomia and immunodeficiency; the pathogenic form of Candida albicans can lead to oral lesions [38 - 41].

Leibovici et al. [27] conducted a prospective study comparing the prevalence of Candida on the tongue of patients with psoriasis, AD patients and normal controls. In the study, the tests for different fungal species were performed, and the results showed that the prevalence of Candida on the tongues of patients with psoriasis was significantly greater (32\%) than in AD patients (18\%). However, Javad et al. [22] carried out a study with AD patients and healthy individuals to detect Candida colonization and to verify the Candida-specific humoral response in patients with AD. Oral cavity and skin samples were collected from the participants. Candida albicans was isolated from the skin and oral cavity of $23 \%$ of the AD patients, whereas only $6 \%$ of the control group presented Candida albicans. Unlike Leibovici et al. [24], Javad et al. [22] evaluated Candida albicans-specific IgG levels and observed significantly lower values in AD patients compared to their controls.

Mouth breathing causes alterations or deficiencies in the saliva-mediated defense mechanisms of oral tissues, possibly resulting in a greater risk for the development of oral diseases, such as caries and periodontal disease [25]. Mouth breathing has also been correlated, in some studies, to gingivitis and periodontitis, which are associated with chronic skin diseases such as urticaria [25]. An individual who breaths through the mouth presents alterations in the defense mechanisms of oral tissues resulting from exposure to air during respiration, which predisposes gingivitis and the risk of cariogenic activity. Koga et al. [42] correlated mouth breathing with the presence of Streptococcus mutans in saliva comparing 30 mouth-breathing patients between the ages of six and 11 years old, and 30 nasal breathing children of the same age who had no apparent caries lesions in the oral cavity. The results showed a high prevalence of Streptococcus mutans in $70 \%$ of mouth breathers and $43.3 \%$ of the controls, indicating a higher tendency for cariogenic activity. Yamaguchi et al. [29] conducted a study with children (2-6 years old) to verify the association between mouth breathing and atopic dermatitis. These authors used 1036 questionnaires and received 468 replies that indicated that atopic dermatitis was related to mouth breathing in the day and at night [26]. Perugia et al. [30], also in 2015, found a high prevalence of mouth breathing in children with atopic dermatitis. These results show that this habit is related to $\mathrm{AD}$ characteristics, affects the quality of life of the patients and causes sleep disturbances, especially due to pruritus and urticaria that are caused by the disease [28]. Habits such as mouth breathing and thumb sucking are factors that negatively influence the craniofacial region. Mouth breathing usually alters dental and facial morphology and is associated with allergic conditions such as asthma, rhinitis and atopic dermatitis, among others, while thumb sucking has psychological and behavioral associations [29]. Consequences of these habits, interconnecting their duration, intensity and frequency, are neuromuscular changes that in most cases can produce overexertion (thumb sucking) or open bite, overjet and crossbite (mouth breathing) [29].

Another factor that can cause oral health problems is stress, which has already been considered as one of the triggers for $\mathrm{AD}$ exacerbations [11]. These patients may also present psychological stress due to their stigmatization, social isolation and discrimination; factors that may, in turn, contribute to the worsening of the signs and symptoms of the disease [20, 21]. Mizawa et al. [28] showed that salivary cortisol levels in AD patients were high when compared to 
healthy controls, and were related to the severity of $\mathrm{AD}$, according to SCORAD, indicating that they may experience chronic stress.

In addition to psychological stress, mechanical stress can also influence the oral health of patients with AD. This issue is particularly relevant for orthodontic treatment, since the tensile and tension forces promoted in the treatment act as factors of bone remodeling. Some disorders such as allergy and asthma predispose greater root resorption [43, 44]. In an analogous way, it has already been demonstrated, through an animal model, that there is an excessive presence of osteoclasts and root resorption gaps in individuals with cutaneous manifestations of AD after orthodontic movement $[45,46]$. Given that several proinflammatory cytokines have already been detected in an orthodontic forced induced resorption process, and that the expression of these factors was found to be higher in the periodontal ligaments of AD mice compared to the controls, where both groups were submitted to tooth movement [46, 47]. Later, these phenotypes were also observed in the dental pulp [46]. In order to elucidate the mechanical basis of the process, an in vitro study demonstrated that cells from dental pulp and periodontal ligament that were submitted to stress enhanced secretion of pro-inflammatory factors by interleukin 17- producing T CD4+ lymphocytes [45, 46]. This suggests a key role of dental pulp and periodontal ligament in the process of root resorption induced by orthodontic movement, since the stimulation of osteoclastogenesis mediated by Th17 cells after this mechanical stress [47] has already been demonstrated. Interleukin (IL)-17 is an inflammatory cytokine and an important mediator in root resorption induced by the inflammatory process of orthodontic treatment. This cytokine is present in the mediation of autoimmune diseases such as rheumatoid arthritis, multiple sclerosis and psoriasis and has recently been correlated with the pathogenesis of AD by some authors. Thus, orthodontic movement in AD patients possibly induces greater root resorption, due to the higher levels of Th17 cells in the peripheral blood of these individuals, which demonstrates a direct relation with the severity of the disease [48].

An important factor that may also contribute to the hypothesis that patients with AD have a higher frequency of carious lesions, as observed in the studies of Igawa et al. [21] and Perugia et al. [30], is that atopic dermatitis promotes dysfunction in the epidermal barrier, consequently decreasing its protective function against allergens in the skin and favoring microbial colonization [30,49]. Thus, these patients would be more prone to the onset of dental caries which is one of the most common infectious diseases, especially in childhood [49]. Mutations in the Fillaggrin Gene (FLG) may also be associated with the pathogenesis of dental caries, since it has an expression in oral mucosa [50]. Although not all $\mathrm{AD}$ patients harbor a mutation in this gene (only 60\%), its dysfunction impairs proper formation of the skin barrier. Based in what is observed in filaggrin-deficient skin, it is reasonable that absence of filaggrin in oral mucosa promotes greater susceptibility to dryness and infections caused by microorganisms such as Streptococcus mutans, the most common agent of dental caries [30, 51 - 54].

Based on the articles mentioned above in this review, we have demonstrated a possible relationship between oral health and the condition of the patient with atopic dermatitis, not only from physiological aspects, but also taking into account the microbiological, psychological and individual habits of AD patients.

\section{CONCLUSION}

Some oral manifestations, such as odontogenic infections, candidiasis and mouth breathing, are often diagnosed in patients with atopic dermatitis and may also be directly associated with the worsening of this disease. Thus, careful oral examination in patients with AD should be performed so that the quality of life of these patients can be improved. However, the development of new studies is necessary in order to have a better understanding of oral manifestations and atopic dermatitis.

\section{CONSENT FOR PUBLICATION}

Not applicable.

\section{CONFLICT OF INTEREST}

The author declared no conflict of interest, financial or otherwise.

\section{ACKNOWLEDGEMENTS}

During the preparation of this study, the authors Aline Domingues Tavares Oliveira and Camila Stofella Sodré had similar contribution. 
This study was supported by the National Council for Scientific and Technological Development (CNPq); the Coordination for the Improvement of Higher Education Personnel (CAPES), Brasilia, Brazil; and the Foundation for Research Support of Rio de Janeiro State (FAPERJ), Rio de Janeiro, Brazil.

\section{REFERENCES}

[1] Camelo-Nunes IC, Wandalsen GF, Melo KC, Naspitz CK, Solé D. Prevalência de eczema atópico e sintomas relacionados entre estudantes. J Pediatr 2004; 80: 60-4. [http://dx.doi.org/10.2223/1135]

[2] Borges WG, Burns DAR, Guimarães FATM, Felizola MLBM. Dermatite atópica em adolescentes do Distrito Federal. Comparação entre as fases I e III do ISAAC, de acordo com a situação socioeconômica. Rev bras alerg imunopatol 2008; 31(4): 146-50.

[3] Hanifin JM. Diagnostic features of atopic dermatitis. Acta derm venereol (Stockh) 1980; 92: pp. 44-7.

[4] Kapoor R, Menon C, Hoffstad O, Bilker W, Leclerc P, Margolis DJ. The prevalence of atopic triad in children with physician-confirmed atopic dermatitis. J Am Acad Dermatol 2008; 58(1): 68-73. [http://dx.doi.org/10.1016/j.jaad.2007.06.041] [PMID: 17692428]

[5] Odhiambo JA, Williams HC, Clayton TO, Robertson CF, Asher MI. Global variations in prevalence of eczema symptoms in children from ISAAC Phase Three. J Allergy Clin Immunol 2009; 124(6): 1251-8.e23. [http://dx.doi.org/10.1016/j.jaci.2009.10.009] [PMID: 20004783]

[6] Krafchik BR. Atopic Dermatitis. In: Schachner LA, Hansen RC. Ed, Pediatric Dermatology. $4^{\text {nd }}$ ed. Elsevier - Saunders, Mosby, Churchill $2011 ; 851-66$

[7] Kumar MK, Singh PK, Patel PK. Clinico-immunological profile and their correlation with severity of atopic dermatitis in Eastern Indian children. J Nat Sci Biol Med 2014; 5(1): 95-100. [http://dx.doi.org/10.4103/0976-9668.127296] [PMID: 24678205]

[8] Schultz-Larsen F, Hanifin J. Epidemiology of atopic dermatitis. Immunol Allergy Clin North Am 2002; 22 : 1-24. [http://dx.doi.org/10.1016/S0889-8561(03)00066-3]

[9] Gerasimov SV, Vasjuta VV, Myhovych OO, Bondarchuk LI. Probiotic supplement reduces atopic dermatitis in preschool children: A randomized, double-blind, placebo-controlled, clinical trial. Am J Clin Dermatol 2010; 11(5): 351-61. [http://dx.doi.org/10.2165/11531420-000000000-00000] [PMID: 20642296]

[10] Hannuksela A, Väänänen A. Predisposing factors for malocclusion in 7-year-old children with special reference to atopic diseases. Am J Orthod Dentofacial Orthop 1987; 92(4): 299-303. [http://dx.doi.org/10.1016/0889-5406(87)90330-1] [PMID: 3477948]

[11] Yoshida M, Amatsu A. Asymptomatic shedding of herpes simplex virus into the oral cavity of patients with atopic dermatitis. J Clin Virol 2000; 16(1): 65-9. [http://dx.doi.org/10.1016/S1386-6532(99)00057-8] [PMID: 10680743]

[12] Assimakopoulos D, Patrikakos G, Fotika C, Elisaf M. Benign migratory glossitis or geographic tongue: An enigmatic oral lesion. Am J Med 2002; 113(9): 751-5. [http://dx.doi.org/10.1016/S0002-9343(02)01379-7] [PMID: 12517366]

[13] Marks R, Scarff CE, Yap LM, Verlinden V, Jolley D, Campbell J. Fungiform papillary glossitis: Atopic disease in the mouth? Br J Dermatol 2005; 153(4): 740-5. [http://dx.doi.org/10.1111/j.1365-2133.2005.06577.x] [PMID: 16181454]

[14] Shulman JD, Carpenter WM. Prevalence and risk factors associated with geographic tongue among US adults. Oral Dis 2006; 12(4): 381-6. [http://dx.doi.org/10.1111/j.1601-0825.2005.01208.x] [PMID: 16792723]

[15] Gelmetti Carlo. La scuola dell'atopia. In: MENNI, S. Dermatite atopica: Patologie orali., Milano: Springer, 2007. cap.16.

[16] Deckers IAG, McLean S, Linssen S, Mommers M, van Schayck CP, Sheikh A. Investigating international time trends in the incidence and prevalence of atopic eczema 1990-2010: A systematic review of epidemiological studies. PLoS One 2012; 7(7): e39803. [http://dx.doi.org/10.1371/journal.pone.0039803] [PMID: 22808063]

[17] Shaw TE, Currie GP, Koudelka CW, Simpson EL. Eczema prevalence in the United States: Data from the 2003 National Survey of Children's Health. J Invest Dermatol 2011; 131(1): 67-73. [http://dx.doi.org/10.1038/jid.2010.251] [PMID: 20739951]

[18] Williams HC, Burney PG, Pembroke AC, Hay RJ. The U.K. Working Party’s Diagnostic Criteria for Atopic Dermatitis. III. Independent hospital validation. Br J Dermatol 1994; 131(3): 406-16. [http://dx.doi.org/10.1111/j.1365-2133.1994.tb08532.x] [PMID: 7918017]

[19] Misery L. Therapeutic perspectives in atopic dermatitis. Clin Rev Allergy Immunol 2011; 41(3): 267-71. [http://dx.doi.org/10.1007/s12016-010-8226-y] [PMID: 21188650]

[20] Chi AC, Neville BW, Krayer JW, Gonsalves WC. Oral manifestations of systemic disease. Am Fam Physician 2010; 82(11): 1381-8. [PMID: 21121523] 
[21] Igawa K, Nishioka K, Yokozeki H. Odontogenic focal infection could be partly involved in the pathogenesis of atopic dermatitis as exacerbating factor. Int J Dermatol 2007; 46(4): 376-9. [http://dx.doi.org/10.1111/j.1365-4632.2007.03101.x] [PMID: 17442076]

[22] Javad G, Taheri Sarvtin M, Hedayati MT, Hajheydari Z, Yazdani J, Shokohi T. Evaluation of Candida colonization and specific humoral responses against Candida albicans in patients with Atopic Dermatitis. BioMed Res Int 2015; 2015: 849206. [http://dx.doi.org/10.1155/2015/849206] [PMID: 25945349]

[23] Chellaih P, Sivadas G, Chintu S, Vaishnavi Vedam VK, Arunachalam R, Sarsu M. Effect of anti-asthmatic drugs on dental health: A comparative study. J Pharm Bioallied Sci 2016; 8(Suppl. 1): S77-80. [PMID: 27829752]

[24] Gouvea-Mondim MEB, Hofling JF. Colonization of the oral cavity of children by Candida spp: Role in the etiology of dental caries. Rev Inst Cienc Saúde 2005; 23(4): 315-25.

[25] Faergemann J. Atopic dermatitis and fungi. Clin Microbiol Rev 2002; 15(4): 545-63. [http://dx.doi.org/10.1128/CMR.15.4.545-563.2002] [PMID: 12364369]

[26] Rother ET. Systematic review X narrative review. Acta Paul Enferm 2007; 20(2): v-vi. [http://dx.doi.org/10.1590/S0103-21002007000200001]

[27] Leibovici V, Alkalay R, Hershko K, et al. Prevalence of Candida on the tongue and intertriginous areas of psoriatic and atopic dermatitis patients. Mycoses 2008; 51(1): 63-6. [PMID: 18076597]

[28] Mizawa M, Yamaguchi M, Ueda C, Makino T, Shimizu T. Stress evaluation in adult patients with atopic dermatitis using salivary cortisol. BioMed Res Int 2013; 2013: 138027. [http://dx.doi.org/10.1155/2013/138027] [PMID: 23971022]

[29] Yamaguchi H, Tada S, Nakanishi Y, et al. Association between mouth breathing and atopic dermatitis in Japanese children 2-6 years old: A population-based cross-sectional study. PLoS One 2015; 10(4): e0125916. [http://dx.doi.org/10.1371/journal.pone.0125916] [PMID: 25915864]

[30] Perugia C, Saraceno R, Ventura A, et al. Atopic dermatitis and dental manifestations. G Ital Dermatol Venereol 2017; $152(2)$ : 122-5. [PMID: 26446571]

[31] Flohr C, Mann J. New insights into the epidemiology of childhood atopic dermatitis. Allergy 2014; 69(1): 3-16. [http://dx.doi.org/10.1111/all.12270] [PMID: 24417229]

[32] Valinoti AC, da Costa LC Jr, Farah A, Pereira de Sousa V, Fonseca-Gonçalves A, Maia LC. Are pediatric antibiotic formulations potentials risk factors for dental caries and dental erosion? Open Dent J 2016; 10: 420-30. [http://dx.doi.org/10.2174/1874210601610010420] [PMID: 27583053]

[33] Rubel D, Thirumoorthy T, Soebaryo RW, et al. Consensus guidelines for the management of atopic dermatitis: An Asia-Pacific perspective. J Dermatol 2013; 40(3): 160-71.

[http://dx.doi.org/10.1111/1346-8138.12065] [PMID: 23289827]

[34] Niebuhr M, Mai U, Kapp A, Werfel T. Antibiotic treatment of cutaneous infections with Staphylococcus aureus in patients with atopic dermatitis: Current antimicrobial resistances and susceptibilities. Exp Dermatol 2008; 17(11): 953-7. [http://dx.doi.org/10.1111/j.1600-0625.2008.00734.x] [PMID: 18557929]

[35] Araujo MR, Grégio AMT. Azevedo de LR, Machado MAN, Mattioli T, Castro de LFA. Reações adversas medicamentosas de interesse odontológico. Rev Odontol Araçatuba 2005; 26(2): 28-33.

[36] Liu X, Liu H, Guo Z, Luan W. Association of asymptomatic oral candidal carriage, oral candidiasis and CD4 lymphocyte count in HIVpositive patients in China. Oral Dis 2006; 12(1): 41-4. [http://dx.doi.org/10.1111/j.1601-0825.2005.01155.x] [PMID: 16390467]

[37] Naglik JR, Challacombe SJ, Hube B. Candida albicans secreted aspartyl proteinases in virulence and pathogenesis. Microbiol Mol Biol Rev 2003; 67(3): 400-28.

[http://dx.doi.org/10.1128/MMBR.67.3.400-428.2003] [PMID: 12966142]

[38] Scheutz F, Matee MI, Simon E, et al. Association between carriage of oral yeasts, malnutrition and HIV-1 infection among Tanzanian children aged 18 months to 5 years. Community Dent Oral Epidemiol 1997; 25(3): 193-8. [http://dx.doi.org/10.1111/j.1600-0528.1997.tb00925.x] [PMID: 9192146]

[39] Gonçalves LS, Júnior AS, Ferreira SMS, et al. Factors associated with specific clinical forms of oral candidiasis in HIV-infected Brazilian adults. Arch Oral Biol 2013; 58(6): 657-63. [http://dx.doi.org/10.1016/j.archoralbio.2012.10.007] [PMID: 23123068]

[40] Jacob LS, Flaitz CM, Nichols CM, Hicks MJ. Role of dentinal carious lesions in the pathogenesis of oral candidiasis in HIV infection. J Am Dent Assoc 1998; 129(2): 187-94.

[http://dx.doi.org/10.14219/jada.archive.1998.0176] [PMID: 9495050]

[41] Portela MB, Souza IPR, Costa EMMB, Hagler AN, Soares RMA, Santos ALS. Differential recovery of Candida species from subgingival sites in human immunodeficiency virus-positive and healthy children from Rio de Janeiro, Brazil. J Clin Microbiol 2004; 42 (12): $5925-7$. [http://dx.doi.org/10.1128/JCM.42.12.5925-5927.2004] [PMID: 15583343] 
[42] Koga-Ito CY, Unterkircher CS, Watanabe H, Martins CA, Vidotto V, Jorge AO. Caries risk tests and salivary levels of immunoglobulins to Streptococcus mutans and Candida albicans in mouthbreathing syndrome patients. Caries Res 2003; 37(1): 38-43. [http://dx.doi.org/10.1159/000068225] [PMID: 12566638]

[43] Nishioka K, Saito A, Akiyama K, Yasueda H. Effect of home environment control on children with atopic or non-atopic asthma. Allergol Int 2006; 55(2): 141-8. [http://dx.doi.org/10.2332/allergolint.55.141] [PMID: 17075250]

[44] McNab S, Battistutta D, Taverne A, Symons AL. External apical root resorption of posterior teeth in asthmatics after orthodontic treatment. Am J Orthod Dentofacial Orthop 1999; 116(5): 545-51.

[http://dx.doi.org/10.1016/S0889-5406(99)70187-3] [PMID: 10547515]

[45] Shimizu M, Yamaguchi M, Fujita S, Utsunomiya T, Yamamoto H, Kasai K. Interleukin-17/T-helper 17 cells in an atopic dermatitis mouse model aggravate orthodontic root resorption in dental pulp. Eur J Oral Sci 2013; 121(2): 101-10. [http://dx.doi.org/10.1111/eos.12024] [PMID: 23489899]

[46] Yamada K, Yamaguchi M, Asano M, Fujita S, Kobayashi R, Kasai K. Th17-cells in atopic dermatitis stimulate orthodontic root resorption. Oral Dis 2013; 19(7): 683-93. [http://dx.doi.org/10.1111/odi.12053] [PMID: 23279451]

[47] Hayashi N, Yamaguchi M, Nakajima R, Utsunomiya T, Yamamoto H, Kasai K. T-helper 17 cells mediate the osteo/odontoclastogenesis induced by excessive orthodontic forces. Oral Dis 2012; 18(4): 375-88. [http://dx.doi.org/10.1111/j.1601-0825.2011.01886.x] [PMID: 22229652]

[48] Koga C, Kabashima K, Shiraishi N, Kobayashi M, Tokura Y. Possible pathogenic role of Th17 cells for atopic dermatitis. J Invest Dermatol 2008; 128(11): 2625-30 [http://dx.doi.org/10.1038/jid.2008.111] [PMID: 18432274]

[49] Krakowski AC, Eichenfield LF, Dohil MA. Management of atopic dermatitis in the pediatric population. Pediatrics 2008; $122(4)$ : 812-24. [http://dx.doi.org/10.1542/peds.2007-2232] [PMID: 18829806]

[50] De Benedetto A, Qualia CM, Baroody FM, Beck LA. Filaggrin expression in oral, nasal, and esophageal mucosa. J Invest Dermatol 2008; 128(6): 1594-7. [http://dx.doi.org/10.1038/sj.jid.5701208] [PMID: 18172455]

[51] Akdis CA, Akdis M, Bieber T, et al. European academy of allergology and clinical immunology/american academy of allergy asthma and immunology: Diagnosis and treatment of atopic dermatitis in children and adults: European Academy of Allergology and Clinical Immunology/American Academy of Allergy, Asthma and Immunology/PRACTALL Consensus Report. J Allergy Clin Immunol 2006; 118(1): 152-69.

[http://dx.doi.org/10.1016/j.jaci.2006.03.045] [PMID: 16815151]

[52] Incorvaia C, Frati F, Verna N, D’Alò S, Motolese A, Pucci S. Allergy and the skin. Clin Exp Immunol 2008; 153(Suppl. 1): $27-9$. [http://dx.doi.org/10.1111/j.1365-2249.2008.03718.x] [PMID: 18721326]

[53] Fonacier LS, Dreskin SC, Leung DYM. Allergic skin diseases. J Allergy Clin Immunol 2010; 125(2)(Suppl. 2): S138-49. [http://dx.doi.org/10.1016/j.jaci.2009.05.039] [PMID: 19932921]

[54] Lluis A, Schaub B. Lesson from the farm environment. Curr Opin Allergy Clin Immunol 2012; 12(2): 158-63. [http://dx.doi.org/10.1097/ACI.0b013e32835109a8] [PMID: 22306551]

\section{(C) 2018 Oliveira et al.}

This is an open access article distributed under the terms of the Creative Commons Attribution 4.0 International Public License (CC-BY 4.0), a copy of which is available at: (https://creativecommons.org/licenses/by/4.0/legalcode). This license permits unrestricted use, distribution, and reproduction in any medium, provided the original author and source are credited. 